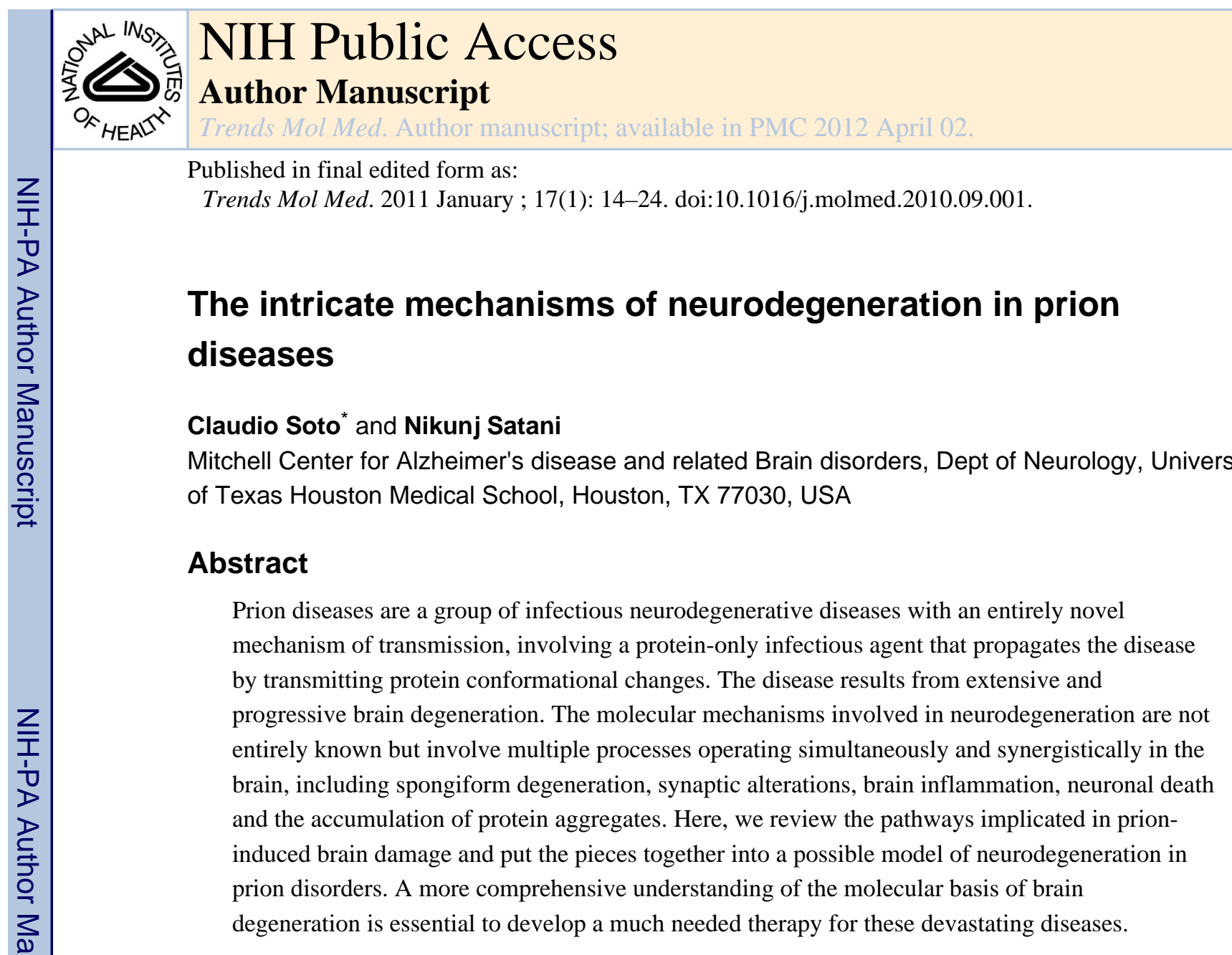

\title{
Keywords
}

Prions; apoptosis; neurodegeneration; brain inflammation; spongiform degeneration; protein misfolding; synaptic alterations

\section{Prions and prion diseases}

Prion diseases, also known as transmissible spongiform encephalopathies (TSEs) are a group of fatal neurodegenerative diseases affecting humans as well as animals, including Creutzfeldt-Jakob disease (CJD), Fatal familial insomnia, Gerstmann-Sträussler-Scheinker and Kuru in humans; scrapie in sheep and goats; bovine spongiform encephalopathy in cattle; and chronic wasting disease in cervids. Although the clinical profiles differ among the distinct prion diseases, the characteristics of brain damage are similar and include: extensive spongiform degeneration, widespread neuronal loss, synaptic alterations, atypical brain inflammation and the accumulation of protein aggregates (Figure 1) [1].

\footnotetext{
*To whom correspondence should be addressed. University of Texas Houston Medical School, 6431 Fannin St, Houston, TX 77030. Tel 713-5007086; Fax 713-5000667; Claudio.Soto@uth.tmc.edu.

Publisher's Disclaimer: This is a PDF file of an unedited manuscript that has been accepted for publication. As a service to our customers we are providing this early version of the manuscript. The manuscript will undergo copyediting, typesetting, and review of the resulting proof before it is published in its final citable form. Please note that during the production process errors may be discovered which could affect the content, and all legal disclaimers that apply to the journal pertain.
} 
The diseases can originate sporadically, by transmission, or by inheritance. Although sporadic disease is the most common in humans, the transmissible form has attracted the most attention. The diseases can be transmitted within and between species by several mechanisms, including ingestion, iatrogenic transmission and blood transfusion [2]. The possibility for spreading through environmental exposure cannot be discounted, because the infectious agent (called a prion) persists in the environment for many years [3].

The unorthodox nature of the infectious agent has been the most investigated aspect of prion diseases [4]. Prions appear to be composed exclusively of a protein (Box 1), which is a conformational isoform of the cellular prion protein $\left(\mathrm{PrP}^{\mathrm{C}}\right)$ that is expressed predominantly in the brain and lymphatic tissues [2]. $\mathrm{PrP}^{\mathrm{Sc}}$ refers to the misfolded infectious form that differs from $\operatorname{PrP}^{\mathrm{C}}$ because it has a higher content of $\beta$-sheet structure and it aggregates to form medium and large size polymers. The conversion of $\mathrm{PrP}^{\mathrm{C}}$ into $\mathrm{PrP}^{\mathrm{Sc}}$ is the main event in prion disease (Box 1) [2,4]; however, the mechanism by which this process results in brain damage and disease is largely unknown.

\section{Box 1}

\section{Prions: the protein-only infectious agents that transmit disease}

The prion or protein-only hypothesis proposes that the sole component of the infectious agent in TSEs is a misfolded version of the prion protein $\left(\mathrm{PrPSc}^{\mathrm{Sc}}\right.$, which replicates by converting the normally-folded host-associated cellular prion protein $\left(\operatorname{PrP}^{\mathrm{C}}\right)$ into the misfolded form [2]. Compelling data have established that $\mathrm{PrP}^{\mathrm{Sc}}$ is indeed the basic element of the infectious agent $[2,109]$.

The infectious agent is too small to be a bacteria or virus

Infectivity is not removed by treatments that destroy nucleic acids

Injection of highly pure $\mathrm{PrP}^{\mathrm{Sc}}$ induces prion disease in animals

Infectivity is proportional to the concentration of $\mathrm{PrP}^{\mathrm{Sc}}$

In general, $\mathrm{PrP}^{\mathrm{Sc}}$ is detectable only in individuals affected by the disease

All inherited cases of prion disease are associated with mutations in the PrP gene

Transgenic animals overexpressing the mutant PrP gene develop neurologic dysfunction, spongiform brain degeneration and symptoms that mimic those seen in scrapie infected animals

PrP knockout mice are resistant to prion infection

$\mathrm{PrP}^{\mathrm{Sc}}$ self-propagates in vitro by inducing the misfolding of $\mathrm{PrP}^{\mathrm{C}}$

In vitro replication of $\mathrm{PrP}^{\mathrm{Sc}}$ generates infectious material using $\operatorname{PrP}^{\mathrm{C}}$ from entire brain homogenates, purified mammalian $\operatorname{PrP}^{\mathrm{C}}$ or recombinant $\operatorname{PrP}^{\mathrm{C}}$

De novo production of $\mathrm{PrP}^{\mathrm{Sc}}$ either from mammalian or bacterial origin produces infectious material with novel characteristics 
The phenomena of prion strains, species barrier, strain adaptation and prion memory are enciphered in the folding of $\mathrm{PrP}^{\mathrm{Sc}}$ and can be reproduced during in vitro prion replication

In most cases of prion disease, there are no recognizable gross abnormalities in the brain [1]; however, patients who survive for several years show variable degrees of cerebral atrophy comparable to those observed in other neurodegenerative diseases. Typical neuropathological changes associated with prion diseases include vacuolation of the neuropil in the gray matter, synaptic alterations, prominent neuronal loss, exuberant reactive astrogliosis and a variable degree of cerebral accumulation of prion protein aggregates (Figure 1) [1]. The relative contribution of these changes to brain dysfunction and disease is not well known. Here, we describe the available data regarding the mechanisms of these neurodegenerative changes and their putative role in the disease pathogenesis.

Understanding the molecular basis of brain damage might facilitate the discovery of novel therapeutic targets for prion diseases.

\section{The central role of PrPSc}

There is little doubt that the formation and slow but progressive accumulation of $\operatorname{PrP}^{\mathrm{Sc}}$ in the brain is the triggering factor of neurodegeneration and disease. However, the mechanism by which $\mathrm{PrP}^{\mathrm{Sc}}$ is involved in the disease pathogenesis is mostly unknown. $\mathrm{PrP}^{\mathrm{Sc}}$ accumulates in different brain regions as distinct types of deposits depending on the animal species and strains of the agent. The most characteristic patterns of $\mathrm{PrPSc}^{\mathrm{Sc}}$ deposition are diffuse accumulations that can be synaptic, patchy/perivacuolar or prominent perineuronal deposits surrounding neuronal bodies and processes [1,5]. In some cases (such as variant CJD, Kuru and Gerstmann-Sträussler-Scheinker disease), amyloid plaques similar to those typically observed in Alzheimer's disease can be observed [6].

The loss of a critical biological function of $\mathrm{PrP}^{\mathrm{C}}$ is one possible mechanism by which $\mathrm{PrP}^{\mathrm{Sc}}$ formation might result in neurodegeneration [7]. Numerous studies have proposed various functions for $\mathrm{PrP}^{\mathrm{C}}$, including a role in neuroprotection, apoptosis, oxidative stress, transmembrane signaling, cell adhesion, myelination, trafficking of metal ions and involvement in synaptic activity (Box 2) [7,8]. However, there is still no consensus with respect to the biological function of the protein. Nevertheless, compelling evidence coming from studies with PrP null mice indicate that the disease does not result from the loss of physiological function of $\mathrm{PrP}^{\mathrm{C}}$ [7]. Indeed, permanent or conditional deletion of Prnp in mice does not produce any major phenotype $[9,10]$.

\section{Box 2}

\section{Putative biological functions of PrPC}

$\mathrm{PrP}^{\mathrm{C}}$ is a highly conserved protein in mammals and a many putative cellular functions have been proposed $[8,110]$; however, none of these functions have been convincingly demonstrated. $\mathrm{PrPC}^{\mathrm{C}}$ is located at the cell surface, mostly associated with membrane lipid rafts, where it is attached by a carboxyl-terminal glycophosphatidilinositol anchor. Not surprisingly given its localization in signaling molecule-rich lipid rafts, $\operatorname{PrP}^{\mathrm{C}}$ has been 
implicated in a signal transduction pathway leading to neuroprotection [111-113]. Neuroprotective and antioxidative functions for $\mathrm{PrP}^{\mathrm{C}}$ are perhaps the most consistent biological activities attributed to the protein $[110,114]$. In cell culture, through interaction with known signaling proteins, $\operatorname{PrP}^{\mathrm{C}}$ might be a cellular receptor for neuroprotective signals $[112,113,115]$. $\mathrm{PrP}^{\mathrm{C}}$ might also protect against cell death by directly inhibiting Bax-induced apoptosis [114,116]. This activity depends on the presence of Bcl2 homology domains in PrP, mostly in the region of the third -helix. A possible role of $\mathrm{PrPC}^{\mathrm{C}}$ as a cellular receptor for the amyloid-beta oligomers implicated in Alzheimer's disease has been suggested [117]; however, this remains controversial $[118,119]$.

Another widely studied putative function for $\operatorname{PrP}^{\mathrm{C}}$ involves the binding and metabolism of copper and other divalent metals [120]. At physiological concentrations, the octapeptide repeat of $\mathrm{PrP}^{\mathrm{C}}$ binds copper [121,122]. In animal models, significant changes in the levels of copper have been detected in the brains of scrapie-infected mice before the onset of disease symptoms [123,124]. Interaction with copper and other metals could also impact the conversion of $\operatorname{PrP}^{\mathrm{C}}$ to $\mathrm{PrP}^{\mathrm{Sc}}$ by either modulating directly the conversion or changing the turnover rate of the protein. $\mathrm{PrP}^{\mathrm{C}}$ might also play a major role in cellular iron uptake and transport [125]. Indeed, changes in iron homeostasis are a common feature of prion infected cells and mouse models.

Studies with PrP knockout mice have not been very useful to determine the function of $\mathrm{PrP}^{\mathrm{C}}$, because the removal of the protein produces mild phenotypes. However, the subtle abnormalities in these animals [126] include alterations in neuronal transmission and electrical activity, defective neurogenesis, alterations in circadian rhythm and increased sensitivity to hypoxia, ischemia, and seizures. Ablation of $\operatorname{PrP}^{\mathrm{C}}$ triggers a chronic demyelinating polyneuropathy in mice [127]; this phenotype depended on the deletion of the protein from neurons and could be suppressed by neuronal $\operatorname{PrP}^{\mathrm{C}}$ expression. These results indicate that neuronal $\mathrm{PrP}^{\mathrm{C}}$ expression might be essential for myelin maintenance.

Another possible mechanism by which $\mathrm{PrP}^{\mathrm{Sc}}$ formation might be linked to the disease is by direct toxicity of the misfolded protein. This mechanism is appealing considering that several neurodegenerative diseases including Alzheimer's disease, Parkinson's disease, Amyotrophic lateral sclerosis, Huntington's disease and various forms of cerebral ataxia also appear to be caused by the accumulation of misfolded proteins in the brain (Box 3) [11]. Support for the hypothesis that misfolded protein aggregates are neurotoxic comes from observations that the accumulation of the aggregates occurs in areas of the brain most damaged in each of the diseases and from in vitro experiments showing that misfolded oligomers are directly toxic to neurons in culture [11].

\section{Box 3}

\section{Common mechanisms of neurodegeneration between prion diseases and other neurodegenerative disorders}

Neurodegenerative diseases are some of the most devastating human maladies, affecting skilled movements, feelings, thinking, cognition and memory. This group of diseases includes highly prevalent disorders such as Alzheimer's disease (AD) and Parkinson's 
disease (PD), and other less common, such as Hungtinton's disease (HD), spinocerebellar ataxias, Amyotrophic lateral sclerosis and prion diseases. In spite of the important differences in clinical manifestation, neurodegenerative disorders share some common features, including an appearance late in life, extensive neuronal loss and synaptic abnormalities and the presence of cerebral deposits of misfolded protein aggregates [11]. These deposits are a typical disease signature and although in each disease the main protein component is different, they have similar morphological, structural and staining characteristics. Compelling evidence suggests that in all of these diseases, the accumulation of misfolded protein aggregates is the triggering factor in the pathology and leads to atypical brain inflammation, synaptic and dendrite loss and neuronal apoptosis [11]. Moreover, growing evidence indicates that the initiation of the clinical disease might be associated with synaptic damage caused by small oligomeric misfolded proteins. The natural defense mechanisms mounted by the body to combat the pathology also seem similar and include induction of the UPR, inflammatory cascades and autophagy. Strikingly, recent exciting data suggest that various neurodegenerative diseases (such as AD, PD and HD) might be transmissible by infection with the misfolded protein in a similar way as prion diseases $[128,129]$. Therefore, the molecular pathways implicated in diverse neurodegenerative diseases are remarkably similar, indicating that knowledge accumulated in one disease could be extrapolated to the other diseases and that common therapeutic strategies might be developed to combat these destructive diseases.

$\operatorname{PrP}$ synthetic peptides and more relevantly highly purified $\mathrm{PrP}^{\mathrm{Sc}}$ from the brain of infected animals induce damage when cells are exposed to sufficient quantities [12-14]. Incubation of murine neuroblastoma cells with nanomolar concentrations of $\mathrm{PrP}^{\mathrm{Sc}}$ produces substantial endoplasmic reticulum (ER) stress [13]. In support of these in vitro observations, histological and biochemical analysis of brains from scrapie-sick mice and from humans affected by sporadic and variant CJD revealed ER stress markers in areas with substantial accumulation of $\operatorname{PrP}^{\mathrm{Sc}}$ [13]. ER stress produced by $\operatorname{PrP}^{\mathrm{Sc}}$ accumulation during prion infection changes $\operatorname{PrP}^{\mathrm{C}}$ trafficking, leading to the formation of potentially neurotoxic forms of $\operatorname{PrP}[15,16]$. The ER is a subcellular compartment that functions in the secretory pathway that synthesizes, modifies and delivers proteins to appropriate subcellular locations [17]. Almost all secreted and membrane proteins, including $\operatorname{PrP}^{\mathrm{C}}$, attain their folded conformation in the ER. The correct folding of a protein inside the ER involves proper post-translational modifications such as glycosylation and disulfide bond formation as in the case of $\operatorname{PrP}^{\mathrm{C}}$. The ER manages misfolded proteins by either attempting to correct their folding or targeting them for degradation [18-20]. Sustained and chronic accumulation of misfolded proteins leads to ER stress and the activation of the Unfolded Protein Response (UPR) [18-20]. UPR consist of three different and parallel mechanisms: (i) translational attenuation to decrease the load of misfolded proteins in the ER; (ii) transcriptional activation of ER resident chaperones (including $\mathrm{BiP} /($ glucose regulated protein) grp78, Protein Disulfide Isomerase, grp94 and grp58) to combat misfolding; and (iii) the activation of ER associated degradation (ERAD) of proteins by directing them to the cytosol for clearance by the $26 \mathrm{~S}$ proteosome. The UPR protects the ER, but prolonged ER stress caused by the sustained accumulation of misfolded proteins activates cell death pathways $[18,20]$. 
The concept that neurodegeneration is caused by the formation and accumulation of $\operatorname{PrP}^{\mathrm{Sc}}$ is probably an oversimplification. Despite a good correlation between $\operatorname{PrP}^{\mathrm{Sc}}$ accumulation, neurodegeneration and disease in the large majority of the cases, there are rare cases in which disease appear in the absence of detectable $\operatorname{PrP}^{\mathrm{Sc}}[21]$ and in which abundant $\mathrm{PrP}^{\mathrm{Sc}}$ deposition is observed with no neurodegeneration or disease [22]. These results suggest that $\mathrm{PrP}^{\mathrm{Sc}}$ is neither necessary nor sufficient for the disease. However, an alternative explanation is that in rare cases, $\mathrm{PrP}^{\mathrm{Sc}}$ might have different biochemical properties that make detection difficult or render it not toxic enough to cause disease. These observations could suggest that the replicative and infectious form of $\mathrm{PrP}^{\mathrm{Sc}}$ is not the same as the neurotoxic form [23]. The most toxic form could be composed of small misfolded oligomers that might not be detectable as $\mathrm{PrP}^{\mathrm{Sc}}$ by the classical biochemical assays. Alternatively, minor isoforms of $\mathrm{PrP}^{\mathrm{Sc}}$, including transmembrane or cytosolic versions of the misfolded protein, could be the neurotoxic species [24,25]. Another possibility is that $\mathrm{PrP}^{\mathrm{Sc}}$ subverts or modifies the normal function of $\operatorname{PrP}^{\mathrm{C}}[8,26]$. In this scenario, the biological function of $\operatorname{PrP}^{\mathrm{C}}$ might be altered by binding to $\mathrm{PrP}^{\mathrm{Sc}}$, and for example activate an alternative signal transduction pathway that leads to neurotoxicity rather than neuroprotection. $\mathrm{PrP}^{\mathrm{Sc}}$ might produce this effect by crosslinking cell-surface $\mathrm{PrP}^{\mathrm{C}}$, which induces neuronal apoptosis in vivo [27], or by binding to and blocking specific functional domains of $\operatorname{PrP}^{\mathrm{C}}$.

An issue that has been extensively investigated is whether $\mathrm{PrP}^{\mathrm{C}}$ needs to be expressed in neuronal cells for apoptosis to occur. Early studies in which neural tissue overexpressing $\operatorname{PrP}^{\mathrm{C}}$ was grafted into the brain of PrP knockout mice showed that upon prion infection, the grafts accumulated high levels of $\mathrm{PrP}^{\mathrm{Sc}}$ and developed brain damage characteristic of scrapie [28]. Interestingly, substantial amounts of $\mathrm{PrP}^{\mathrm{Sc}}$ generated in the grafted tissue migrated into the host brain. However, no pathological changes were seen in PrP-deficient tissue containing $\operatorname{PrP}^{\mathrm{Sc}}$ [28]. These findings indicate that $\mathrm{PrP}^{\mathrm{C}}$ expression in neurons is required for brain damage. Additional support for this conclusion came from experiments with PrP conditional knockout mice, showing that the early symptoms and neuropathological alterations induced by prion infection can be reversed upon elimination of $\mathrm{PrP}^{\mathrm{C}}$ expression [29]. Interestingly, neurodegeneration was reversed despite the persistence of preformed $\mathrm{PrP}^{\mathrm{Sc}}$ in other brain cells. In a series of interesting experiments, transgenic mice expressing $\mathrm{PrP}^{\mathrm{C}}$ exclusively in specific cellular types (neurons, astrocytes, lymphocytes and hepatocytes) were challenged with prions. Animals expressing $\operatorname{PrP}^{\mathrm{C}}$ in neurons alone or in astrocytes alone but not in hepatocytes or T lymphocytes were susceptible to scrapie infection and disease [30-32]. Finally, recent studies using transgenic mice expressing $\mathrm{PrP}^{\mathrm{C}}$ not attached to the membrane showed a dissociation between prion replication and toxicity [26]. In hemizygous transgenic mice expressing only anchorless $\mathrm{PrP}^{\mathrm{C}}$, large quantities of $\mathrm{PrP}^{\mathrm{Sc}}$ accumulated in the brain but the animals did not exhibit extensive neurodegeneration or disease [26]. These results suggest that anchoring of the protein to the cell membrane is required for the disease. However, prion infection of homozygous transgenic mice expressing two-fold more anchorless $\mathrm{PrP}^{\mathrm{C}}$ produced a disease with different behavioral and neuropathological abnormalities, including lack of spongiform degeneration [33]. Interestingly, tissue grafting studies suggested that anchored $\operatorname{PrP}^{\mathrm{C}}$ expression was required for spongiosis during prion infection. 
In summary, $\operatorname{PrP}^{\mathrm{C}}$ to $\operatorname{PrP}^{\mathrm{Sc}}$ conversion is a central feature of prion disease and possibly the first abnormality occurring in the disease. Although both $\operatorname{PrP}^{\mathrm{C}}$ and $\mathrm{PrP}^{\mathrm{Sc}}$ isoforms have been associated with biological and pathological activities, the exact contribution of the prion protein conversion to the process of brain degeneration is not completely understood.

\section{Brain dysfunction begins at the synapse}

Although cell death and spongiform degeneration are cardinal features of prion disease, the first detectable changes appear to be associated with neuronal dysfunction at the synapse $[34,35]$. Using a murine model of prion infection, significant impairment of burrowing, nesting and glucose consumption, and increased open field activity were observed months before any detectable neuronal loss [36]. These initial behavioral changes appear concomitantly with $\mathrm{PrP}^{\mathrm{Sc}}$ deposition and synaptic alterations. The most likely explanation for these results is that the initial stage of prion disease is associated with synaptic dysfunction, possibly induced by $\mathrm{PrP}^{\mathrm{Sc}}$ accumulation. Indeed, synaptic abnormalities were detected around the time that the first signs of behavioral impairment appeared and long before neuronal death in mice [35,37]. Studies in knockout mice are also consistent with PrP affecting synaptic function $[38,39]$. $\operatorname{PrP}^{\mathrm{C}}$ is enriched in the synapses of the central nervous system (CNS) and neuromuscular junctions [40,41] and interacts with proteins involved in synaptic transmission such as synaptophysin [42]. In histological studies, $\mathrm{PrP}^{\mathrm{Sc}}$ staining is punctuate around the neuronal cell bodies and dendrites, which is almost identical to synaptophysin, suggesting that $\mathrm{PrP}^{\mathrm{Sc}}$ accumulates in synaptic structures [43,44]. At early stages of the disease, $\mathrm{PrP}^{\mathrm{Sc}}$ accumulates in membrane lipid rafts, detaching caveolin and synaptophysin from these membrane domains, which likely impacts synaptic activity [37]. Decreased expression of proteins linked to exocytosis and neurotransmission (such as synaptophysin, SNAP-25, synapsins, syntaxins and Rab3a) in the cerebral cortex and cerebellum have also been reported in cases of sporadic CJD [45]. Collectively, these data suggest that $\operatorname{PrP}^{\mathrm{C}}$ to $\operatorname{PrP}^{\mathrm{Sc}}$ conversion could impact the integrity and function of synapses, leading to neurological damage and initiating the clinical disease. Strikingly, in other neurodegenerative diseases associated with cerebral accumulation of misfolded proteins, the initial stage of the disease is also associated with synaptic dysfunction rather than neuronal loss [46-48].

Synaptic dysfunction is followed by dendritic loss, with both alterations preceding neuronal death [49]. Dendritic losses correlate with spongiform degeneration in the early stages of prion disease. Although the mechanism responsible for dendritic loss is not clear, it might involve changes in the expression and cleavage of Notch-1 [50]. Increasing the levels of the Notch-1 intracellular domain (NICD) causes dendritic atrophy by inhibiting the growth of dendrites. Interestingly, $\mathrm{PrP}^{\mathrm{Sc}}$ alters NICD production in animal models of scrapie and in vitro in $\mathrm{N} 2 \mathrm{~A}$ cells [50].

Further support for the concept that synaptic dysfunction in the absence of neuronal death is responsible for the early alterations in prion diseases come from a series of studies from Mallucci and colleagues [51,52]. Using mice where $\mathrm{PrP}^{\mathrm{C}}$ is deleted exclusively in neurons postnatally, the early neuropathological and behavioral abnormalities associated with the disease were reversed after the expression of the PrP gene was shut down. This occurred 
despite the accumulation of extraneuronal $\operatorname{PrP}^{\mathrm{Sc}}$ to levels seen in terminally ill wild-type animals [51]. Thus, the propagation of non-neuronal $\mathrm{PrP}^{\mathrm{Sc}}$ is not pathogenic. These data suggest that the cause of the neuropathological changes was not an irreversible event, such as the loss of neurons, but was a reversible process, such as synaptic or neuronal dysfunction [53]. These findings are not only important to understand the mechanisms of neurodegeneration but also suggest that early intervention with an effective therapy could lead to substantial recovery of patients.

\section{The intriguing spongiform degeneration}

The most typical brain alteration in prion diseases is vacuolation, giving to the brain the appearance of a sponge and hence the name of Spongiform encephalopathies. Spongiform degeneration consists of diffuse or focally clustered, small, round or oval vacuoles in the neuropil of the deep cortical layers, cerebellar cortex or subcortical gray matter, which might become confluent [54]. The spongiform changes arise from the cisternae of the neuronal smooth ER, the astrocytic and presynaptic axodendritic and axosomatic processes [1]. They might also result from the intracellular digestion in the lysosomal compartment. The spongiform changes can be mild, moderate or severe and affect different areas of the brain. The degree and distribution of vacuolation is often used to classify the disease and determine the strain of the infectious agent [55].

The molecular mechanisms responsible for vacuolation and the significance of spongiform degeneration in prion diseases remain unclear. Spongiosis might result from abnormal membrane permeability and increased water content within neuronal processes [56]. It might also result from autophagy [57]. The accumulation of $\operatorname{PrP}^{\mathrm{Sc}}$ within the lysosomal compartment in neuronal processes could be the precursor to spongiform changes in TSEs [58]. The involvement of the endosomal-lysosomal system in tissue pathology is consistent with an old observation: vacuolization is suppressed in TSE-infected mink of the ChediakHigashi genotype, and these animals have abnormalities in their membrane-bound organelles (including lysosomes) and are deficient for lysosomal enzymes [59]. Vacuolation could be a nonspecific spongiform change, occurring secondary to a disruption of axonal transport [60]. Finally, Perry's group argues that spongiform degeneration is an artifact that arises during the fixation and processing of the brain tissue [61]. Indeed, when tissue is stained without fixation, no vacuolation is observed, whereas extensive spongiosis is seen when similar samples are first fixed and paraffin-embedded.

Several studies have analyzed the relationships among $\operatorname{PrP}^{\mathrm{Sc}}$ accumulation, vacuolization and neuronal death in TSE and have shown temporal and spatial dissociation of these processes [62,63]. Interestingly, in the Malluci studies with the PrP conditional knockout mice, depleting neuronal $\mathrm{PrP}^{\mathrm{C}}$ at the onset of disease symptoms reversed spongiosis despite the persistence of substantial $\mathrm{PrP}^{\mathrm{Sc}}$ deposits in the brain [51,52]. These findings suggest that vacuolation is independent of $\mathrm{PrP}^{\mathrm{Sc}}$ accumulation.

Although spongiform degeneration is the most typical brain alteration in TSEs, we know little about its mechanism of origin and the relationship between spongiform degeneration 
and other neuropathological abnormalities. Much more research is needed to elucidate the molecular basis for the intriguing spongiform brain damage in TSEs.

\section{Atypical brain inflammation}

Compared to the extensive and severe inflammatory response observed in some neurological diseases, such as brain injury or multiple sclerosis, prion diseases were not originally associated with brain inflammation. However, it is clear that prion diseases involve widespread glial activation within the brain following prion infection. Thus, today's view is that brain inflammation is prominent in prion disease, but it is unusual because it consists mainly of the activation of astrocytes and microglia with very little or no lymphocyte infiltration [64]. The contribution of inflammation to brain dysfunction and disease onset is however mostly unclear.

The inflammatory response in prion disease occurs mostly via the activation of microglia, which are the immune cells of the CNS that are activated in response to infection or injury. Upon accumulation of $\mathrm{PrP}^{\mathrm{Sc}}$ deposits, microglia are activated and attracted to the site of injury, sometimes involving migration of the cells within the brain [65]. It is also possible that the accumulation of $\mathrm{PrP}^{\mathrm{Sc}}$ in peripheral tissues can activate $\mathrm{T}$ cells. Activated T cells, unlike naïve $\mathrm{T}$ cells, can cross the blood-brain barrier and produce proinflammatory cytokines [66]. Activated T cells can directly recruit and activate microglia. After activation, microglia upregulate certain proteins including complement factors, proteins of the major histocompatibility complex, proinflammatory cytokines and interleukins [67]. If the level of activation of these factors is appropriate, they guide antigen presentation, which promotes phagocytosis and thereby neuroprotection. By contrast, if there is excessive and chronic activation of these factors, the immune system goes into overdrive and produces oxidative stress, which leads to neurotoxicity and subsequently to neurodegeneration. A role for astrocyte activation during prion neuroinflammation has also been reported; astrocytes appear to be regulated by interleukin-1 (IL-1) [68], which induces astrocyte activation through the CXCR3 ligand. Changes in the expression of some CXC ligands can be detected even in asymptomatic stages of the disease, suggesting that chemokines might play a pivotal role in promoting neurodegeneration in prion diseases [69].

An important question is whether glial activation is triggered by accumulation of $\mathrm{PrP}^{\mathrm{Sc}}$ directly or rather by neurodegenerative changes in neurons owing to prion replication. Answering this question is relevant, because it will enable scientists to assess whether inflammation is a cause or a consequence of neuronal degeneration. A recent systems biology study found that genes associated with microglial proliferation and astrocytosis are upregulated after a substantial quantity of $\mathrm{PrP}^{\mathrm{Sc}}$ is detectable in the brain but well before any signs of disease or neuronal damage are evident [70]. These findings indicate that brain inflammation might be a direct response to $\mathrm{PrP}^{\mathrm{Sc}}$. A similar conclusion was obtained by neuropathological time-course studies showing that astrocyte and microglia activation occur many weeks before neuronal loss and coincide with the earliest changes in neuronal morphology [64,71]. However, despite the time and space correlations, there is no compelling evidence that astrogliosis plays any role in neuronal damage. The in vitro neurotoxic activity of aggregates of the PrP fragment (residues 106-126) is enhanced in the 
presence of microglia $[72,73]$. However, the relevance of these in vitro experiments, working with isolated cells and large concentrations of a nonphysiological peptide, is questionable. Alternatively, activated microglia could play a positive role in removing $\mathrm{PrP}^{\mathrm{Sc}}$ deposits and thereby slowing down brain degeneration [74]. The possibility that microglia are capable of phagocytizing $\operatorname{PrP}^{\mathrm{Sc}}$ aggregates has not been carefully evaluated, but spleen macrophages actively participate in the clearance of scrapie inoculum delivered intraperitoneally [75].

In transgenic mice expressing $\operatorname{PrP}^{\mathrm{C}}$ only in neurons or in multiple brain cells, intraocular prion infection led to $\mathrm{PrP}^{\mathrm{Sc}}$ replication and astroglial activation [76]; however, only transgenic mice expressing $\mathrm{PrP}^{\mathrm{C}}$ in multiple cells exhibited microglial activation and retinal degeneration. In addition, retinal gliosis and $\mathrm{PrP}^{\mathrm{Sc}}$ accumulation in these animals preceded retinal degeneration, indicating that the activation of both astrocytes and microglia appeared to be an early response to prion infection [76].

In summary, in prion diseases as well as other more prevalent neurodegenerative disorders, the inflammatory response is both protective and damaging. It seems likely that both outcomes are possible depending on the extent to which $\mathrm{PrP}^{\mathrm{Sc}}$ stimulates the production of proinflammatory factors and the severity of inflammation [71].

\section{Neuronal death as the final killer}

Notwithstanding the fact that synaptic dysfunction and dendritic loss appear to be responsible for the onset of the clinical symptoms and that spongiform degeneration and $\mathrm{PrPSc}^{\mathrm{Sc}}$ accumulation are the most specific neuropathological alterations, extensive neuronal loss is the main cause of the chronic brain deterioration and the fatal outcome of prion disease. Neuronal death is a prominent feature of all prion diseases and there is a good correlation between the type of clinical symptoms observed in each disease and the brain regions exhibiting the greatest extent of cell death [1]. The mechanisms responsible for neuronal death in prion disease are not well defined but at least two main pathways have been implicated: autophagy and apoptosis. It is also important to highlight that there is increasing evidence that autophagy and apoptosis share several common regulatory elements and mechanisms [77].

\section{Autophagy}

Autophagy is an intracellular degradation system that digests organelles and most long-lived proteins and is also the primary form of nonapoptotic cellular demise [78]. During macroautophagy, cellular organelles and the proteins therein are sequestered in a doublelayered vesicle called an autophagosome. In the cytoplasm, autophagosomes fuse with a lysosome to form an autophagolysosome. The contents inside autophagolysosomes are degraded by lysosomal hydrolases. Autophagy has been implicated in various physiological processes including protein and organelle turnover, stress responses, cellular differentiation and programmed cell death [79]. Autophagy might be a protective mechanism to fight disease at the cellular level through the digestion of misfolded toxic aggregates [80]. Indeed, induction of autophagy by trehalose or lithium significantly reduced $\mathrm{PrP}^{\mathrm{Sc}}$ in a dose- and time-dependent manner in persistently prion-infected neuronal cells [81,82]. Conversely, 
inhibition of autophagy counteracted the antiprion effect of trehalose. These findings provide evidence that the induction of autophagy enhances the cellular degradation of prions [81]. However, dysfunction of autophagy in certain pathological situations can trigger and mediate programmed cell death [78]. Much more research is necessary to understand whether autophagy is primarily a strategy for survival or can also be part of a cell death program.

Autophagolysosomes form vacuoles known as autophagic vacuoles [77] that are present in samples from TSE patients [83]. Based on the presence of large autophagic vacuoles in the cytoplasm of neurons, Liberski and colleagues proposed that autophagy plays an important role in prion disease neurodegeneration and might participate in the spongiform changes apparent in TSEs [83]. More studies are needed to investigate this interesting possibility.

\section{Apoptosis}

Several studies in humans and in mouse models of prion diseases (infectious models, hereditary models with mutated PrPs and transgenic models overexpressing wild-type PrP) indicate that neuronal dysfunction and death occur via apoptosis (for references see [84]).

Apoptosis is a programmed form of cell death that plays a central role during development and homeostasis of multicellular organisms and is also implicated in pathological conditions. The central executioner molecules of apoptosis are a large family of cysteine proteases known as caspases [85]. Based on structural similarities, substrate preference and their role in the apoptotic pathway, caspases have been divided into initiators (such as caspase- 8 and caspase-9), downstream executor caspases (such as caspase-3) and inflammatory caspases (such as caspase-1). The activation of caspase-dependent apoptosis can be initiated by the activation of death receptors or by mitochondrial stress. More recently, another apoptotic-regulatory pathway has been described, in which the induction of ER stress, owing to alteration of calcium homeostasis or the accumulation of misfolded proteins, triggers the activation of the ER-resident caspase-12 [86]. In recent years, many reports have linked the ER-stress apoptosis pathway to diverse neurodegenerative diseases related to protein misfolding and aggregation [19].

Apoptosis induced by aggregated PrP peptide fragments or mutant PrP variants (such as truncated or cytosolic PrP) proceeds via the mitochondrial pathway [87-89] (Figure 2). Indeed, important roles for the well-known regulators of the mitochondrial apoptosis pathway Bcl2 (B-cell lymphoma protein 2) and Bax (Bcl-2-associated $\times$ protein) have been reported $[88,90]$. However, two studies showed that neither Bax deletion nor Bcl-2 overexpression decrease neuronal death induced by prion infection or alter the progression of prion disease in animals [91,92]. These findings suggest that apoptosis in prion disease might be induced by mechanisms other than the mitochondrial pathway.

Neurons exposed to purified $\mathrm{PrP}^{\mathrm{Sc}}$ exhibit extensive ER stress, resulting in the rapid release of calcium to the cytoplasm and the activation of the UPR (Figure 2) [93]. The upregulation of caspase-12 (caspase-4 in humans) in vitro and in the brain of prion infected mice and patients with sporadic and variant CJD has been observed [13]. Caspase- 12 normally resides on the ER membrane; however, upon activation, it translocates to the cytoplasm where it 
cleaves downstream caspases [93]. Caspase-3 is also activated in prion-infected cultured cells and the brains of diverse animals and humans affected by TSE [13]. Although caspase-12 and caspase-4 are involved in ER-stress mediated apoptosis, the upstream events leading to their activation are not clear. However, the role of caspase-12 mediated apoptosis in prion disease has been questioned by a recent study showing that caspase-12 deletion did not change the progression of the disease in vivo [94].

Disruption of calcium $\left(\mathrm{Ca}^{2+}\right)$ homeostasis in the cell is probably the most adverse and immediate effect caused by ER stress (Figure 2) [95]. In neurons, the effect of calcium is particularly deleterious, because $\mathrm{Ca}^{2+}$ waves are important for neuronal activity [95]. $\mathrm{Ca}^{2+}$ is a second messenger in cellular signaling pathways; thus, maintaining a specific concentration of $\mathrm{Ca}^{2+}$ in the cytoplasm is critical for normal cellular biology. The ER is the main site for intracellular storage of $\mathrm{Ca}^{2+}$. The presence of misfolded proteins can result in an increase in cytoplasmic $\mathrm{Ca}^{2+}$ owing to ER stress. The release of calcium from the ER to the cytoplasm occurs when cells are exposed to misfolded prion protein $[13,96,97]$. Indeed, $\mathrm{Ca}^{2+}$ release appears to be one of the first changes after prion infection in cells. Increased $\mathrm{Ca}^{2+}$ in the cytoplasm deregulates downstream targets including calcineurin $(\mathrm{CaN})$, a type 2B phosphatase [98]. The activity of this enzyme is regulated by the $\mathrm{Ca}^{2+}$-calmodulin complex. Optimal activity of $\mathrm{CaN}$ is required to maintain the proper phosphorylation state of protein targets, such as the apoptosis inducer Bad, or the transcription factor CREB.

Hyperactivation of $\mathrm{CaN}$ reduces the phosphorylation of $\mathrm{Bad}$, which then disassociates from the scaffolding protein 14-3-3 and interacts with Bax to form channels in the mitochondrial membrane [99]. As a result, cytochrome $\mathrm{C}$ is released into the cytoplasm, leading to caspase activation and finally apoptosis. CREB, which is dephosphorylated by hyperactivated CaN, cannot translocate to the nucleus where it regulates the expression of genes required for synaptic plasticity [100]. CaN activation is implicated in neuronal death induced both by $\mathrm{PrP}^{\mathrm{Sc}}$ and PrP synthetic peptides [101,102]. Moreover, CaN activity increases in the brain at the beginning of the symptomatic phase of prion disease [101]. Strikingly, blocking $\mathrm{CaN}$ activity in sick prion infected mice increases animal survival, decreases the progression of deterioration and reduces neurodegeneration [101]. These data support the idea that $\operatorname{PrP}^{\mathrm{Sc}}$ produces synaptic damage and neuronal death in TSEs through ER stress, changes in calcium homeostasis and the induction of $\mathrm{CaN}$ activity (Figure 2).

In summary, alternative apoptotic pathways operate simultaneously in the brains of animals with prion disease. This could explain why elimination of one route to apoptosis by gene knockout does not alter the progression of the disease substantially. It is also possible that neuronal death is not contributing much to prion disease pathology. A detailed understanding of the exact contribution of neuronal death to prion disease awaits further investigation.

\section{Concluding remarks}

Multiple mechanisms for neurodegeneration have been proposed for prion diseases including synaptic damage, dendritic atrophy, vacuolization, autophagy, microglial activation, oxidative stress, the accumulation of misfolded aggregates, ER stress and apoptosis. The absolute mechanism still remains obscure. It is possible that multiple 
mechanisms contribute to the pathology of prion diseases, culminating in progressive neurodegeneration, rapid clinical deterioration and death.

Although several reports have proposed that $\mathrm{PrP}^{\mathrm{Sc}}$ directly induces cell death, synaptic damage, astrogliosis and spongiform brain degeneration, it is likely that these neurodegeneration pathways are tightly interconnected. In order to understand the relationship between $\mathrm{PrP}^{\mathrm{Sc}}$ deposition and the characteristic neuropathological changes observed in prion diseases, several murine scrapie models have been analyzed in terms of the temporal and spatial relationship among the various neurological abnormalities [103-106]. Based on the available data, we propose a model (Figure 3) in which the primary abnormality is the formation and accumulation of $\operatorname{PrP}^{\mathrm{Sc}}$, first in peripheral tissues and later in the brain. The initial formation of $\mathrm{PrP}^{\mathrm{Sc}}$, either by template conversion upon infection or spontaneous misfolding during sporadic and inherited cases of the disease, begins a long and silent presymptomatic period in which $\mathrm{PrP}^{\mathrm{Sc}}$ accumulates progressively. $\mathrm{PrP}^{\mathrm{Sc}}$ accumulation leads to ER stress and activation of the UPR as a defense mechanism to combat protein misfolding through reduction of overall protein expression and upregulation of various chaperones. Chronic ER stress can directly cause neuronal death and possibly spongiform degeneration. Brain inflammation in the form of reactive astrocytes and activated microglia also begins during the presymptomatic phase and likely begins as a protective mechanism to remove misfolded aggregates. Less clear is when autophagy occurs, but it might also be launched initially as a mechanism to remove protein aggregates and damaged cells. Both inflammation and autophagy become chronic, they could also contribute to neuronal death and perhaps brain vacuolation. If the body cannot reduce and control $\mathrm{PrP}^{\mathrm{Sc}}$ formation and the misfolded aggregates accumulate to high levels, several degenerative process manifest. From the point of view of the clinical disease, the most important consequence of $\mathrm{PrP}^{\mathrm{Sc}}$ might be the induction of synaptic alterations, which are likely responsible for the initial disease symptoms. At this early stage, the disease process might be reversible if the neurological abnormalities can be halted. Progressive synaptic dysfunction leads to dendritic loss, which might be sufficient to induce neuronal death. Extensive neuronal death produced by diverse pathways as well as profuse vacuolization of the brain are likely responsible for the severe clinical deterioration typical of the end stage of the disease, which often results in the death of the individual (Figure 3).

The intricate pathways contributing simultaneously to brain dysfunction pose a challenging, and so far insurmountable, problem for developing a treatment for the disease. Currently there is no therapy available and the disease is inevitably fatal. Assuming that the conversion of $\mathrm{PrP}^{\mathrm{C}}$ into $\mathrm{PrP}^{\mathrm{Sc}}$ is the key event triggering the rest of neurological abnormalities, a logical therapeutic target would be to prevent PrP misfolding and prion replication. This approach has been extensively investigated and some compounds have been identified that decrease prion replication and delay the onset of the disease in animal models $[2,107,108]$. However, in general these compounds produce benefit only when administered during the presymptomatic stage of the disease. It is likely that compounds interfering with prion replication would have little or no benefit to patients with already established clinical disease, because by the time clinical symptoms appear, there is substantial brain damage. Treatment aimed at patients with established symptoms of prion disease would need to attack the cellular pathways implicated in brain damage. Therefore, a complete 
understanding of the underlying mechanisms of neurodegeneration is extremely important to identify relevant targets for intervention (Box 4). From our current knowledge of the molecular basis of prion-induced neurodegeneration, strategies boosting the natural defensive pathways (UPR, brain inflammation, autophagy) or inhibition of the most damaging processes (synaptic loss, spongiform degeneration and neuronal death) might have therapeutic benefit.

\section{Box 4}

\section{Outstanding questions}

Is $\mathrm{PrP}^{\mathrm{Sc}}$ accumulation necessary and sufficient to cause neurodegeneration and disease?

What is the nature of the neurotoxic $\mathrm{PrP}^{\mathrm{Sc}}$ form and is there any structural difference between the infectious and toxic $\operatorname{PrP}^{\mathrm{Sc}}$ species?

Is $\mathrm{PrP}^{\mathrm{C}}$ expression in neurons required for brain degeneration?

What is the mechanism of spongiform brain degeneration and role in the pathogenesis?

Is brain inflammation protective or detrimental in prion diseases?

Is synaptic dysfunction the main cause of the initial clinical symptoms of prion disease?

Does autophagy play a role in prion neurodegeneration? Is it protective or detrimental?

What is the exact contribution of neuronal death to prion disease?

Which of the neurodegeneration pathways are the best targets for therapeutic intervention?

\section{Acknowledgments}

This work was supported in part by NIH grant R01NS050349.

\section{Reference List}

1. Budka H. Neuropathology of prion diseases. Br Med Bull. 2003; 66:121-130. [PubMed: 14522854]

2. Aguzzi A, Calella AM. Prions: protein aggregation and infectious diseases. Physiol Rev. 2009; 89:1105-1152. [PubMed: 19789378]

3. Saunders SE, Bartelt-Hunt SL, Bartz JC. Prions in the environment: occurrence, fate and mitigation. Prion. 2008; 2:162-169. [PubMed: 19242120]

4. Soto C, Castilla J. The controversial protein-only hypothesis of prion propagation. Nat Med. 2004; 10:S63-S67. [PubMed: 15272271]

5. Parchi P, Giese A, Capellari S, Brown P, Schulz-Schaeffer W, et al. Classification of sporadic Creutzfeldt-Jakob disease based on molecular and phenotypic analysis of 300 subjects. Ann Neurol. 1999; 46:224-233. [PubMed: 10443888]

6. Ghetti B, Piccardo P, Frangione B, Bugiani O, Giaccone G, et al. Prion protein amyloidosis. Brain Pathol. 1996; 6:127-145. [PubMed: 8737929] 
7. Hetz C, Maundrell K, Soto C. Is loss of function of the prion protein the cause of prion disorders? Trends Mol Med. 2003; 9:237-243. [PubMed: 12829011]

8. Westergard L, Christensen HM, Harris DA. The cellular prion protein $(\operatorname{PrP}(C))$ : its physiological function and role in disease. Biochim Biophys Acta. 2007; 1772:629-644. [PubMed: 17451912]

9. Bueler H, Fischer M, Lang Y, Bluethmann H, Lipp HP, et al. Normal development and behaviour of mice lacking the neuronal cell-surface PrP protein. Nature. 1992; 356:577-582. [PubMed: 1373228]

10. Mallucci GR, Ratte S, Asante EA, Linehan J, Gowland I, et al. Post-natal knockout of prion protein alters hippocampal CA1 properties, but does not result in neurodegeneration. EMBO J. 2002; 21:202-210. [PubMed: 11823413]

11. Soto C. Unfolding the role of protein misfolding in neurodegenerative diseases. Nat Rev Neurosci. 2003; 4:49-60. [PubMed: 12511861]

12. Ettaiche M, Pichot R, Vincent JP, Chabry J. In vivo cytotoxicity of the prion protein fragment 106-126. J Biol Chem. 2000; 275:36487-36490. [PubMed: 11007766]

13. Hetz C, Russelakis-Carneiro M, Maundrell K, Castilla J, Soto C. Caspase-12 and endoplasmic reticulum stress mediate neurotoxicity of pathological prion protein. EMBO J. 2003; 22:54355445. [PubMed: 14532116]

14. Simoneau S, Rezaei H, Sales N, Kaiser-Schulz G, Lefebvre-Roque M, et al. In vitro and in vivo neurotoxicity of prion protein oligomers. PLoS Pathog. 2007; 3:e125. [PubMed: 17784787]

15. Rane NS, Kang SW, Chakrabarti O, Feigenbaum L, Hegde RS. Reduced translocation of nascent prion protein during ER stress contributes to neurodegeneration. Dev Cell. 2008; 15:359-370. [PubMed: 18804434]

16. Orsi A, Fioriti L, Chiesa R, Sitia R. Conditions of endoplasmic reticulum stress favor the accumulation of cytosolic prion protein. J Biol Chem. 2006; 281:30431-30438. [PubMed: 16908519]

17. Boyce M, Yuan J. Cellular response to endoplasmic reticulum stress: a matter of life or death. Cell Death Differ. 2006; 13:363-373. [PubMed: 16397583]

18. Kim I, Xu W, Reed JC. Cell death and endoplasmic reticulum stress: disease relevance and therapeutic opportunities. Nat Rev Drug Discov. 2008; 7:1013-1030. [PubMed: 19043451]

19. Lin JH, Walter P, Yen TS. Endoplasmic reticulum stress in disease pathogenesis. Annu Rev Pathol. 2008; 3:399-425. [PubMed: 18039139]

20. Malhotra JD, Kaufman RJ. The endoplasmic reticulum and the unfolded protein response. Semin Cell Dev Biol. 2007; 18:716-731. [PubMed: 18023214]

21. Lasmezas CI, Deslys JP, Robain O, Jaegly A, Beringue V, et al. Transmission of the BSE agent to mice in the absence of detectable abnormal prion protein. Science. 1997; 275:402-405. [PubMed: 8994041]

22. Piccardo P, Manson JC, King D, Ghetti B, Barron RM. Accumulation of prion protein in the brain that is not associated with transmissible disease. Proc Natl Acad Sci U S A. 2007; 104:4712-4717. [PubMed: 17360589]

23. Harris DA, True HL. New insights into prion structure and toxicity. Neuron. 2006; 50:353-357. [PubMed: 16675391]

24. Hegde RS, Mastrianni JA, Scott MR, DeFea KA, Tremblay P, et al. A transmembrane form of the prion protein in neurodegenerative disease. Science. 1998; 279:827-834. [PubMed: 9452375]

25. Ma J, Wollmann R, Lindquist S. Neurotoxicity and neurodegeneration when PrP accumulates in the cytosol. Science. 2002; 298:1781-1785. [PubMed: 12386337]

26. Chesebro B, Trifilo M, Race R, Meade-White K, Teng C, et al. Anchorless prion protein results in infectious amyloid disease without clinical scrapie. Science. 2005; 308:1435-1439. [PubMed: 15933194]

27. Solforosi L, Criado JR, McGavern DB, Wirz S, Sanchez-Alavez M, et al. Cross-linking cellular prion protein triggers neuronal apoptosis in vivo. Science. 2004; 303:1514-1516. [PubMed: 14752167]

28. Brandner S, Isenmann S, Raeber A, Fischer M, Sailer A, et al. Normal host prion protein necessary for scrapie-induced neurotoxicity. Nature. 1996; 379:339-343. [PubMed: 8552188] 
29. Laszlo L, Lowe J, Self T, Kenward N, Landon M, et al. Lysosomes as key organelles in the pathogenesis of prion encephalopathies. J Pathol. 1992; 166:333-341. [PubMed: 1355530]

30. Race RE, Priola SA, Bessen RA, Ernst D, Dockter J, et al. Neuron-specific expression of a hamster prion protein minigene in transgenic mice induces susceptibility to hamster scrapie agent. Neuron. 1995; 15:1183-1191. [PubMed: 7576660]

31. Raeber AJ, Race RE, Brandner S, Priola SA, Sailer A, et al. Astrocyte-specific expression of hamster prion protein $(\mathrm{PrP})$ renders PrP knockout mice susceptible to hamster scrapie. EMBO J. 1997; 16:6057-6065. [PubMed: 9321385]

32. Raeber AJ, Sailer A, Hegyi I, Klein MA, Rulicke T, et al. Ectopic expression of prion protein (PrP) in T lymphocytes or hepatocytes of PrP knockout mice is insufficient to sustain prion replication. Proc Natl Acad Sci U S A. 1999; 96:3987-3992. [PubMed: 10097150]

33. Chesebro B, Race B, Meade-White K, LaCasse R, Race R, et al. Fatal transmissible amyloid encephalopathy: a new type of prion disease associated with lack of prion protein membrane anchoring. PLoS Pathog. 2010; 6:e1000800. [PubMed: 20221436]

34. Siskova Z, Page A, O'Connor V, Perry VH. Degenerating synaptic boutons in prion disease: microglia activation without synaptic stripping. Am J Pathol. 2009; 175:1610-1621. [PubMed: 19779137]

35. Jeffrey M, Halliday WG, Bell J, Johnston AR, MacLeod NK, et al. Synapse loss associated with abnormal PrP precedes neuronal degeneration in the scrapie-infected murine hippocampus. Neuropathol Appl Neurobiol. 2000; 26:41-54. [PubMed: 10736066]

36. Cunningham C, Deacon R, Wells H, Boche D, Waters S, et al. Synaptic changes characterize early behavioural signs in the ME7 model of murine prion disease. Eur J Neurosci. 2003; 17:21472155. [PubMed: 12786981]

37. Russelakis-Carneiro M, Hetz C, Maundrell K, Soto C. Prion replication alters the distribution of synaptophysin and caveolin 1 in neuronal lipid rafts. Am J Pathol. 2004; 165:1839-1848. [PubMed: 15509552]

38. Nishida N, Katamine S, Shigematsu K, Nakatani A, Sakamoto N, et al. Prion protein is necessary for latent learning and long-term memory retention. Cell Mol Neurobiol. 1997; 17:537-545. [PubMed: 9353594]

39. Collinge J, Whittington MA, Sidle KC, Smith CJ, Palmer MS, et al. Prion protein is necessary for normal synaptic function. Nature. 1994; 370:295-297. [PubMed: 8035877]

40. Askanas V, Bilak M, Engel WK, Leclerc A, Tome F. Prion protein is strongly immunolocalized at the postsynaptic domain of human normal neuromuscular junctions. Neurosci Lett. 1993; 159:111-114. [PubMed: 8264949]

41. Haeberle AM, Ribaut-Barassin C, Bombarde G, Mariani J, Hunsmann G, et al. Synaptic prion protein immuno-reactivity in the rodent cerebellum. Microsc Res Tech. 2000; 50:66-75. [PubMed: 10871550]

42. Fournier JG, Escaig-Haye F, Billette dV, Robain O. Ultrastructural localization of cellular prion protein (PrPc) in synaptic boutons of normal hamster hippocampus. C R Acad Sci III. 1995; 318:339-344. [PubMed: 7788502]

43. Kitamoto T, Shin RW, Doh-Ura K, Tomokane N, Miyazono M, et al. Abnormal isoform of prion proteins accumulates in the synaptic structures of the central nervous system in patients with Creutzfeldt-Jakob disease. Am J Pathol. 1992; 140:1285-1294. [PubMed: 1351366]

44. Fournier JG, Escaig-Haye F, Grigoriev V. Ultrastructural localization of prion proteins: physiological and pathological implications. Microsc Res Tech. 2000; 50:76-88. [PubMed: 10871551]

45. Ferrer I, Puig B, Blanco R, Marti E. Prion protein deposition and abnormal synaptic protein expression in the cerebellum in Creutzfeldt-Jakob disease. Neuroscience. 2000; 97:715-726. [PubMed: 10842016]

46. Selkoe DJ. Alzheimer's disease is a synaptic failure. Science. 2002; 298:789-791. [PubMed: 12399581]

47. Wishart TM, Parson SH, Gillingwater TH. Synaptic vulnerability in neurodegenerative disease. J Neuropathol Exp Neurol. 2006; 65:733-739. [PubMed: 16896307] 
48. Mallucci GR. Prion neurodegeneration: starts and stops at the synapse. Prion. 2009; 3:195-201. [PubMed: 19887910]

49. Fuhrmann M, Mitteregger G, Kretzschmar H, Herms J. Dendritic pathology in prion disease starts at the synaptic spine. J Neurosci. 2007; 27:6224-6233. [PubMed: 17553995]

50. Ishikura N, Clever JL, Bouzamondo-Bernstein E, Samayoa E, Prusiner SB, et al. Notch-1 activation and dendritic atrophy in prion disease. Proc Natl Acad Sci U S A. 2005; 102:886-891. [PubMed: 15640354]

51. Mallucci G, Dickinson A, Linehan J, Klohn PC, Brandner S, et al. Depleting neuronal PrP in prion infection prevents disease and reverses spongiosis. Science. 2003; 302:871-874. [PubMed: 14593181]

52. Mallucci GR, White MD, Farmer M, Dickinson A, Khatun H, et al. Targeting cellular prion protein reverses early cognitive deficits and neurophysiological dysfunction in prion-infected mice. Neuron. 2007; 53:325-335. [PubMed: 17270731]

53. Soto C. Reversibility of prion-induced neurodegeneration. Lancet Neurol. 2007; 6:294-295. [PubMed: 17362830]

54. Jeffrey M, Scott JR, Williams A, Fraser H. Ultrastructural features of spongiform encephalopathy transmitted to mice from three species of bovidae. Acta Neuropathol (Berl). 1992; 84:559-569. [PubMed: 1462768]

55. Morales R, Abid K, Soto C. The prion strain phenomenon: molecular basis and unprecedented features. Biochim Biophys Acta. 2007; 1772:681-691. [PubMed: 17254754]

56. Kovacs GG, Budka H. Prion diseases: from protein to cell pathology. Am J Pathol. 2008; 172:555565. [PubMed: 18245809]

57. Liberski PP, Sikorska B, Bratosiewicz-Wasik J, Carleton GD, Brown P. Neuronal cell death in transmissible spongiform encephalopathies (prion diseases) revisited: from apoptosis to autophagy. Int J Biochem Cell Biol. 2004; 36:2473-2490. [PubMed: 15325586]

58. Betmouni S, Perry VH, Gordon JL. Evidence for an early inflammatory response in the central nervous system of mice with scrapie. Neuroscience. 1996; 74:1-5. [PubMed: 8843071]

59. Marsh RF, Sipe JC, Morse SS, Hanson RP. Transmissible mink encephalopathy. Reduced spongiform degeneration in aged mink of the Chediak-Higashi genotype. Lab Invest. 1976; 34:381-386. [PubMed: 131218]

60. Williams AE, Van Dam AM, Man AHW, Berkenbosch F, Eikelenboom P, et al. Cytokines, prostaglandins and lipocortin-1 are present in the brains of scrapie-infected mice. Brain Res. 1994; 654:200-206. [PubMed: 7987669]

61. Williams A, Lucassen PJ, Ritchie D, Bruce M. PrP deposition, microglial activation, and neuronal apoptosis in murine scrapie. Exp Neurol. 1997; 144:433-438. [PubMed: 9168844]

62. Armstrong RA, Cairns NJ, Ironside JW, Lantos PL. Quantification of vacuolation ("spongiform change"), surviving neurones and prion protein deposition in eleven cases of variant CreutzfeldtJakob disease. Neuropathol Appl Neurobiol. 2002; 28:129-135. [PubMed: 11972799]

63. Foster J, Goldmann W, Parnham D, Chong A, Hunter N. Partial dissociation of PrP(Sc) deposition and vacuolation in the brains of scrapie and BSE experimentally affected goats. J Gen Virol. 2001; 82:267-273. [PubMed: 11125179]

64. Perry VH, Cunningham C, Boche D. Atypical inflammation in the central nervous system in prion disease. Curr Opin Neurol. 2002; 15:349-354. [PubMed: 12045736]

65. Williams AE, Lawson LJ, Perry VH, Fraser H. Characterization of the microglial response in murine scrapie. Neuropathol Appl Neurobiol. 1994; 20:47-55. [PubMed: 8208340]

66. Aloisi F, Ria F, Adorini L. Regulation of T-cell responses by CNS antigen-presenting cells: different roles for microglia and astrocytes. Immunol Today. 2000; 21:141-147. [PubMed: 10689302]

67. Brown DR. Microglia and prion disease. Microsc Res Tech. 2001; 54:71-80. [PubMed: 11455614]

68. Schultz J, Schwarz A, Neidhold S, Burwinkel M, Riemer C, et al. Role of interleukin-1 in prion disease-associated astrocyte activation. Am J Pathol. 2004; 165:671-678. [PubMed: 15277240]

69. Burwinkel M, Riemer C, Schwarz A, Schultz J, Neidhold S, et al. Role of cytokines and chemokines in prion infections of the central nervous system. Int J Dev Neurosci. 2004; 22:497505. [PubMed: 15465279] 
70. Hwang D, Lee IY, Yoo H, Gehlenborg N, Cho JH, et al. A systems approach to prion disease. Mol Syst Biol. 2009; 5:252. [PubMed: 19308092]

71. Eikelenboom P, Bate C, van Gool WA, Hoozemans JJ, Rozemuller JM, et al. Neuroinflammation in Alzheimer's disease and prion disease. Glia. 2002; 40:232-239. [PubMed: 12379910]

72. Brown DR, Schmidt B, Kretzschmar HA. Role of microglia and host prion protein in neurotoxicity of a prion protein fragment. Nature. 1996; 380:345-347. [PubMed: 8598929]

73. Bate C, Boshuizen RS, Langeveld JP, Williams A. Temporal and spatial relationship between the death of PrP-damaged neurones and microglial activation. Neuroreport. 2002; 13:1695-1700. [PubMed: 12352629]

74. McHattie SJ, Brown DR, Bird MM. Cellular uptake of the prion protein fragment PrP106-126 in vitro. J Neurocytol. 1999; 28:149-159. [PubMed: 10590514]

75. Beringue V, Demoy M, Lasmezas CI, Gouritin B, Weingarten C, et al. Role of spleen macrophages in the clearance of scrapie agent early in pathogenesis. J Pathol. 2000; 190:495-502. [PubMed: 10700001]

76. Kercher L, Favara C, Striebel JF, LaCasse R, Chesebro B. Prion protein expression differences in microglia and astroglia influence scrapie-induced neurodegeneration in the retina and brain of transgenic mice. J Virol. 2007; 81:10340-10351. [PubMed: 17652390]

77. Fimia GM, Piacentini M. Regulation of autophagy in mammals and its interplay with apoptosis. Cell Mol Life Sci. 2010; 67:1581-1588. [PubMed: 20165902]

78. Lee JA. Autophagy in neurodegeneration: two sides of the same coin. BMB Rep. 2009; 42:324330. [PubMed: 19558789]

79. Mizushima N. Physiological functions of autophagy. Curr Top Microbiol Immunol. 2009; 335:7184. [PubMed: 19802560]

80. Moreau K, Luo S, Rubinsztein DC. Cytoprotective roles for autophagy. Curr Opin Cell Biol. 2010; 22:206-211. [PubMed: 20045304]

81. Aguib Y, Heiseke A, Gilch S, Riemer C, Baier M, et al. Autophagy induction by trehalose counteracts cellular prion infection. Autophagy. 2009; 5:361-369. [PubMed: 19182537]

82. Heiseke A, Aguib Y, Riemer C, Baier M, Schatzl HM. Lithium induces clearance of protease resistant prion protein in prion-infected cells by induction of autophagy. J Neurochem. 2009; 109:25-34. [PubMed: 19183256]

83. Liberski PP, Brown DR, Sikorska B, Caughey B, Brown P. Cell death and autophagy in prion diseases (transmissible spongiform encephalopathies). Folia Neuropathol. 2008; 46:1-25. [PubMed: 18368623]

84. Hetz C, Soto C. Protein misfolding and disease: the case of prion disorders. Cell Mol Life Sci. 2003; 60:133-143. [PubMed: 12613663]

85. Degterev A, Boyce M, Yuan JY. A decade of caspases. Oncogene. 2003; 22:8543-8567. [PubMed: 14634618]

86. Nakagawa T, Zhu H, Morishima N, Li E, Xu J, et al. Caspase-12 mediates endoplasmic-reticulumspecific apoptosis and cytotoxicity by amyloid-beta. Nature. 2000; 403:98-103. [PubMed: 10638761]

87. O'Donovan CN, Tobin D, Cotter TG. Prion protein fragment PrP-(106-126) induces apoptosis via mitochondrial disruption in human neuronal SH-SY5Y cells. J Biol Chem. 2001; 276:4351643523. [PubMed: 11533027]

88. Nicolas O, Gavin R, Braun N, Urena JM, Fontana X, et al. Bcl-2 overexpression delays caspase-3 activation and rescues cerebellar degeneration in prion-deficient mice that overexpress aminoterminally truncated prion. FASEB J. 2007

89. Hachiya NS, Watanabe K, Kawabata MY, Jozuka A, Kozuka Y, et al. Prion protein with Y145STOP mutation induces mitochondria-mediated apoptosis and PrP-containing deposits in vitro. Biochem Biophys Res Commun. 2005; 327:894-899. [PubMed: 15649429]

90. Chiesa R, Piccardo P, Dossena S, Nowoslawski L, Roth KA, et al. Bax deletion prevents neuronal loss but not neurological symptoms in a transgenic model of inherited prion disease. Proc Natl Acad Sci U S A. 2005; 102:238-243. [PubMed: 15618403]

91. Coulpier M, Messiaen S, Hamel R, Fernandez dM, Lilin T. Bax deletion does not protect neurons from BSE-induced death. Neurobiol Dis. 2006 
92. Steele AD, King OD, Jackson WS, Hetz CA, Borkowski AW, et al. Diminishing apoptosis by deletion of Bax or overexpression of $\mathrm{Bcl}-2$ does not protect against infectious prion toxicity in vivo. J Neurosci. 2007; 27:13022-13027. [PubMed: 18032675]

93. Hetz CA, Soto C. Stressing Out the ER: A Role of the Unfolded Protein Response in Prion-Related Disorders. Curr Mol Med. 2006; 6:37-43. [PubMed: 16472111]

94. Steele AD, Hetz C, Yi CH, Jackson WS, Borkowski AW, et al. Prion pathogenesis is independent of caspase-12. Prion. 2007; 1:243-247. [PubMed: 19164919]

95. Verkhratsky A, Toescu EC. Endoplasmic reticulum $\mathrm{Ca}(2+)$ homeostasis and neuronal death. J Cell Mol Med. 2003; 7:351-361. [PubMed: 14754504]

96. Florio T, Grimaldi M, Scorziello A, Salmona M, Bugiani O, et al. Intracellular calcium rise through L-type calcium channels, as molecular mechanism for prion protein fragment 106-126induced astroglial proliferation. Biochem Biophys Res Commun. 1996; 228:397-405. [PubMed: 8920926]

97. Silei V, Fabrizi C, Venturini G, Salmona M, Bugiani O, et al. Activation of microglial cells by PrP and beta-amyloid fragments raises intracellular calcium through L-type voltage sensitive calcium channels. Brain Res. 1999; 818:168-170. [PubMed: 9914452]

98. Groenendyk J, Lynch J, Michalak M. Calreticulin, Ca2+, and calcineurin - signaling from the endoplasmic reticulum. Mol Cells. 2004; 17:383-389. [PubMed: 15232210]

99. Wang HG, Pathan N, Ethell IM, Krajewski S, Yamaguchi Y, et al. Ca2+-induced apoptosis through calcineurin dephosphorylation of BAD. Science. 1999; 284:339-343. [PubMed: 10195903]

100. Kingsbury TJ, Bambrick LL, Roby CD, Krueger BK. Calcineurin activity is required for depolarization-induced, CREB-dependent gene transcription in cortical neurons. J Neurochem. 2007; 103:761-770. [PubMed: 17666045]

101. Mukherjee A, Morales-Scheihing D, Gonzalez-Romero D, Green K, Taglialatela G, et al. Calcineurin Inhibition at the Clinical Phase of Prion Disease Reduces Neurodegeneration, Improves Behavioral Alterations and Increases Animal Survival. PLoS Pathogen. 2010

102. Agostinho P, Oliveira CR. Involvement of calcineurin in the neurotoxic effects induced by amyloid-beta and prion peptides. Eur J Neurosci. 2003; 17:1189-1196. [PubMed: 12670307]

103. Bouzamondo-Bernstein E, Hopkins SD, Spilman P, Uyehara-Lock J, Deering C, et al. The neurodegeneration sequence in prion diseases: evidence from functional, morphological and ultrastructural studies of the GABAergic system. J Neuropathol Exp Neurol. 2004; 63:882-899. [PubMed: 15330342]

104. Fraser JR. What is the basis of transmissible spongiform encephalopathy induced neurodegeneration and can it be repaired? Neuropathol Appl Neurobiol. 2002; 28:1-11. [PubMed: 11849558]

105. Mallucci GR. Prion neurodegeneration: starts and stops at the synapse. Prion. 2009; 3:195-201. [PubMed: 19887910]

106. Hetz C, Benavent S, Bieler S, Soto C. Prion protein misfolding and brain degeneration. Curr Med Chem -Immun, Endoc \&Metab Agents. 2003; 3:137-147.

107. Cashman NR, Caughey B. Prion diseases - close to effective therapy? Nat Rev Drug Discov. 2004; 3:874-884. [PubMed: 15459678]

108. Weissmann C, Aguzzi A. Approaches to Therapy of Prion Diseases. Annu Rev Med. 2005; 56:321-344. [PubMed: 15660515]

109. Diaz-Espinoza R, Soto C. Generation of prions in vitro and the protein-only hypothesis. Prion. 2010; 4

110. Sakudo A, Ikuta K. Fundamentals of prion diseases and their involvement in the loss of function of cellular prion protein. Protein Pept Lett. 2009; 16:217-229. [PubMed: 19275734]

111. Hugel B, Martinez MC, Kunzelmann C, Blattler T, Aguzzi A, et al. Modulation of signal transduction through the cellular prion protein is linked to its incorporation in lipid rafts. Cell Mol Life Sci. 2004; 61:2998-3007. [PubMed: 15583862]

112. Mouillet-Richard S, Ermonval M, Chebassier C, Laplanche JL, Lehmann S, et al. Signal transduction through prion protein. Science. 2000; 289:1925-1928. [PubMed: 10988071] 
113. Chiarini LB, Freitas AR, Zanata SM, Brentani RR, Martins VR, et al. Cellular prion protein transduces neuroprotective signals. EMBO J. 2002; 21:3317-3326. [PubMed: 12093733]

114. Roucou X, LeBlanc AC. Cellular prion protein neuroprotective function: implications in prion diseases. J Mol Med. 2005; 83:3-11. [PubMed: 15645198]

115. Zanata SM, Lopes MH, Mercadante AF, Hajj GN, Chiarini LB, et al. Stress-inducible protein 1 is a cell surface ligand for cellular prion that triggers neuroprotection. EMBO J. 2002; 21:33073316. [PubMed: 12093732]

116. Gains MJ, Roth KA, LeBlanc AC. Prion protein protects against ethanol-induced Bax-mediated cell death in vivo. Neuroreport. 2006; 17:903-906. [PubMed: 16738485]

117. Lauren J, Gimbel DA, Nygaard HB, Gilbert JW, Strittmatter SM. Cellular prion protein mediates impairment of synaptic plasticity by amyloid-beta oligomers. Nature. 2009; 457:1128-1132. [PubMed: 19242475]

118. Calella AM, Farinelli M, Nuvolone M, Mirante O, Moos R, et al. Prion protein and Abeta-related synaptic toxicity impairment. EMBO Mol Med. 2010; 2:306-314. [PubMed: 20665634]

119. Balducci C, Beeg M, Stravalaci M, Bastone A, Sclip A, et al. Synthetic amyloid-beta oligomers impair long-term memory independently of cellular prion protein. Proc Natl Acad Sci U S A. 2010; 107:2295-2300. [PubMed: 20133875]

120. Brown DR. Copper and prion diseases. Biochem Soc Trans. 2002; 30:742-745. [PubMed: 12196183]

121. Kramer ML, Kratzin HD, Schmidt B, Romer A, Windl O, et al. Prion protein binds copper within the physiological concentration range. J Biol Chem. 2001; 276:16711-16719. [PubMed: 11278306]

122. Chattopadhyay M, Walter ED, Newell DJ, Jackson PJ, Aronoff-Spencer E, et al. The Octarepeat Domain of the Prion Protein Binds Cu(II) with Three Distinct Coordination Modes at pH 7.4. J Am Chem Soc. 2005; 127:12647-12656. [PubMed: 16144413]

123. Thackray AM, Knight R, Haswell SJ, Bujdoso R, Brown DR. Metal imbalance and compromised antioxidant function are early changes in prion disease. Biochem J. 2002; 362:253-258. [PubMed: 11829763]

124. Choi CJ, Kanthasamy A, Anantharam V, Kanthasamy AG. Interaction of metals with prion protein: Possible role of divalent cations in the pathogenesis of prion diseases. Neurotoxicology. 2006

125. Singh A, Mohan ML, Isaac AO, Luo X, Petrak J, et al. Prion protein modulates cellular iron uptake: a novel function with implications for prion disease pathogenesis. PLoS ONE. 2009; 4:e4468. [PubMed: 19212444]

126. Chiesa R, Harris DA. Fishing for prion protein function. PLoS Biol. 2009; 7:e75. [PubMed: 19338390]

127. Bremer J, Baumann F, Tiberi C, Wessig C, Fischer H, et al. Axonal prion protein is required for peripheral myelin maintenance. Nat Neurosci. 2010; 13:310-318. [PubMed: 20098419]

128. Frost B, Diamond MI. Prion-like mechanisms in neurodegenerative diseases. Nat Rev Neurosci. 2010; 11:155-159. [PubMed: 20029438]

129. Brundin P, Melki R, Kopito R. Prion-like transmission of protein aggregates in neurodegenerative diseases. Nat Rev Mol Cell Biol. 2010; 11:301-307. [PubMed: 20308987]

130. Spilman P, Lessard P, Sattavat M, Bush C, Tousseyn T, et al. A gamma-secretase inhibitor and quinacrine reduce prions and prevent dendritic degeneration in murine brains. Proc Natl Acad Sci U S A. 2008; 105:10595-10600. [PubMed: 18647832] 

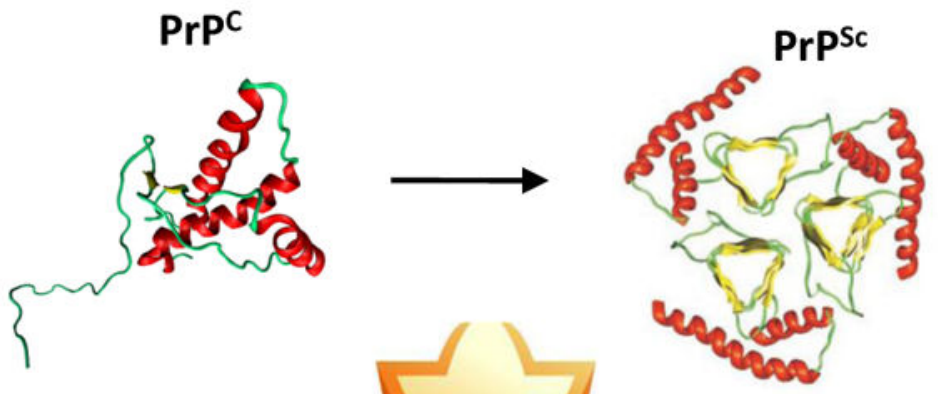

PrPsc deposition

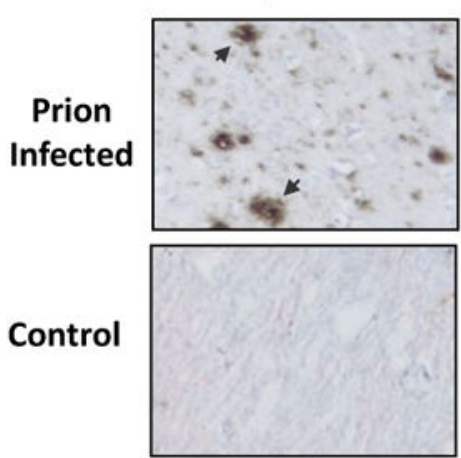

Synaptic and dendrite loss
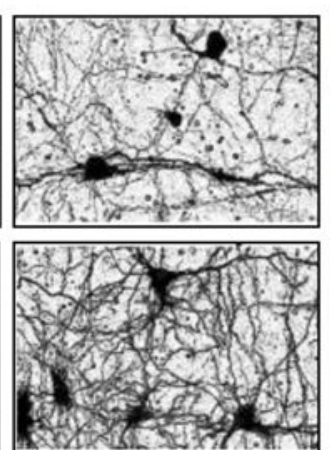

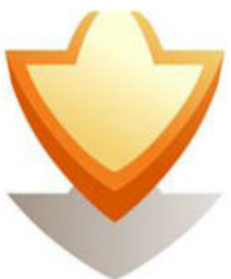

Spongiform degeneration
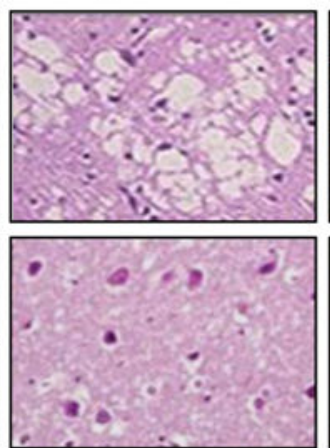

Brain inflammation
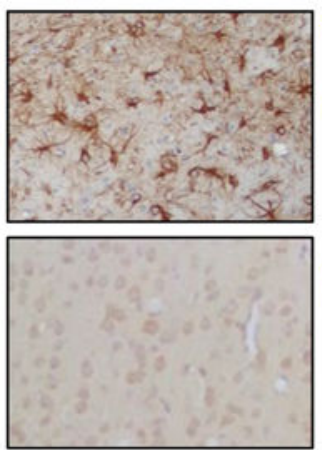

Neuronal death
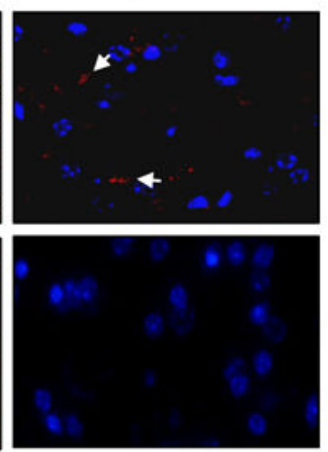

Figure 1. Multiple neurodegenerative pathways are implicated in TSEs

(a) The conversion of the natively folded $\mathrm{PrP}^{\mathrm{C}}$ into $\mathrm{PrPSc}^{\mathrm{Sc}}$ triggers disease. The structure of $\mathrm{PrP}^{\mathrm{C}}$ corresponds to the experimentally determined tridimensional conformation of the protein by nuclear magnetic resonance [91] and the structure of $\mathrm{PrPSc}^{\mathrm{Sc}}$ corresponds to a model based on low resolution techniques [92]. (b) Abnormalities in the brain of infected individuals include the accumulation of $\mathrm{PrPSc}^{\mathrm{Sc}}$ deposits, synaptic damage and dendrite loss, spongiform degeneration, brain inflammation and neuronal death. $\mathrm{PrPSc}^{\mathrm{Sc}}$ deposition was determined after immunohistochemical staining with anti-PrP antibodies (black arrow heads). Dendrites were labeled by Golgi-silver staining to illustrate the substantial decrease on dendrites and synaptic connections in prion infected animals; this picture was reproduced from ref [130] with authorization (Copyright National Academy of Sciences, USA). Spongiform degeneration was evaluated after hematoxylin and eosin staining. Astrogliosis (brain inflammation) was detected by immunohistochemical staining of reactive astrocytes with an anti-GFAP (Glial fibrillary acidic protein) antibody. Apoptosis was detected by staining with caspase- 3 antibody (red indicated by white arrow heads) and DAPI (4',6diamidino-2-phenylindole, blue) staining of nucleus. For each stain, pictures from prion infected (upper) and controls (lower) are shown. 


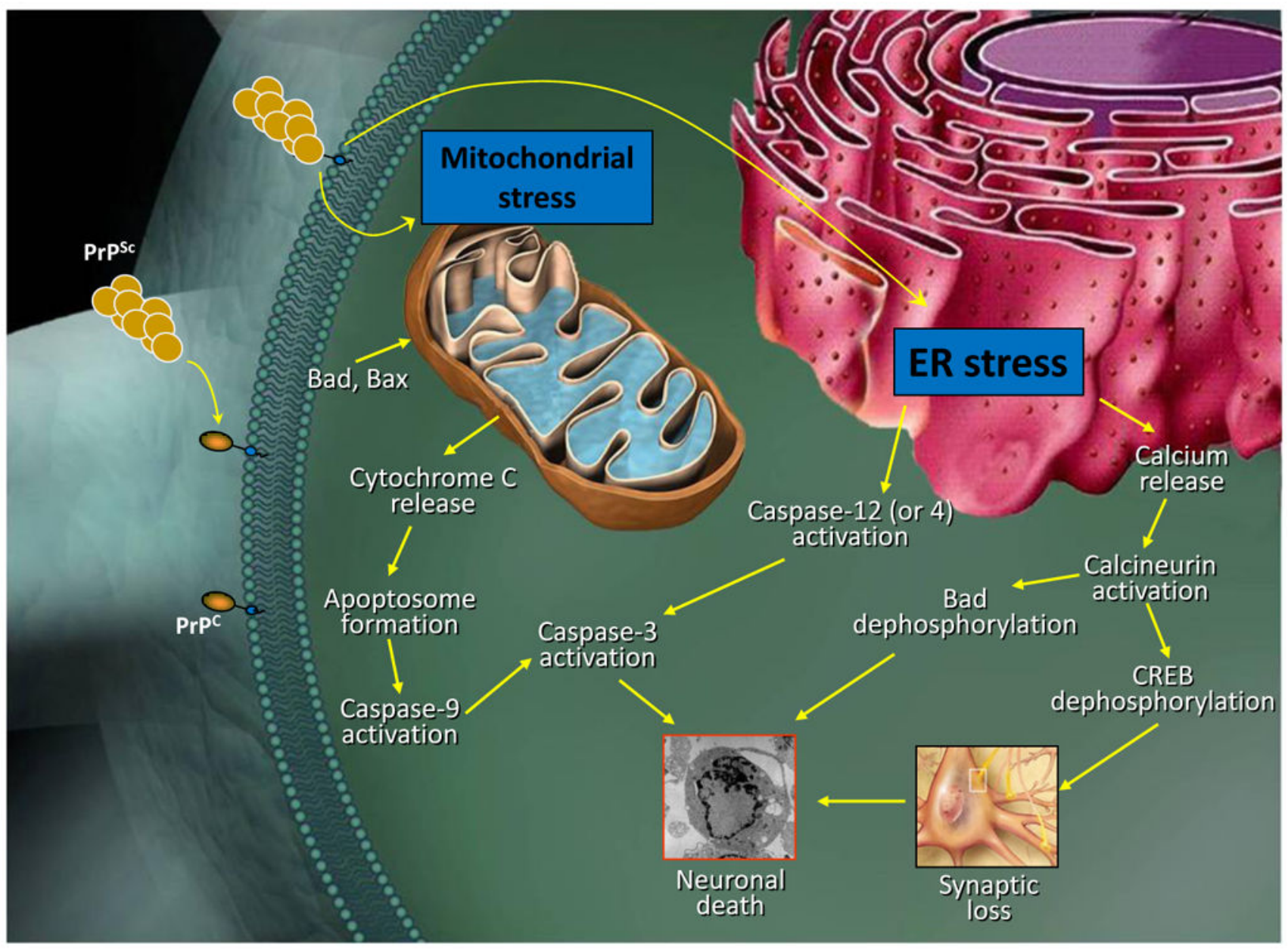

Figure 2. Putative signaling pathways for $\mathrm{PrP}^{\mathrm{Sc}}$-induced neurodegeneration in prion diseases Several mechanisms have been proposed by which $\mathrm{PrP}^{\mathrm{C}}$ to $\mathrm{PrP}^{\mathrm{Sc}}$ conversion results in neurodegeneration. $\mathrm{PrP}^{\mathrm{Sc}}$ might produce mitochondrial stress, leading to apoptosis by the well-known pathway involving translocation of the proapoptotic proteins Bax and Bad and the release of cytochrome $\mathrm{C}$, which forms the apoptosome [85]. Formation of this complex activates caspase-9, which in turn activates the executor caspase-3. An alternative model implicates sustained ER stress [93]. Chronic ER stress results in the activation of the ERresident caspase-12 (caspase-4 in humans), which in turn cleaves and activates caspase-3 [13]. Another proposed mechanism by which ER stress leads to neurodegeneration involves hyperactivation of the phosphatase calcineurin owing to extensive calcium release from the ER. Activated calcineurin dephosphorylates several important proteins, including the transcription factor CREB and the proapoptotic protein Bad, resulting in synaptic damage and neuronal death. Several or all of these pathways and perhaps others (such as autophagy or neuronal death induced by synaptic and dendritic loss) could be operating simultaneously in the brain of prion-infected individuals, which would explain why knocking out one specific signaling pathway does not substantially change the progression of the disease. 


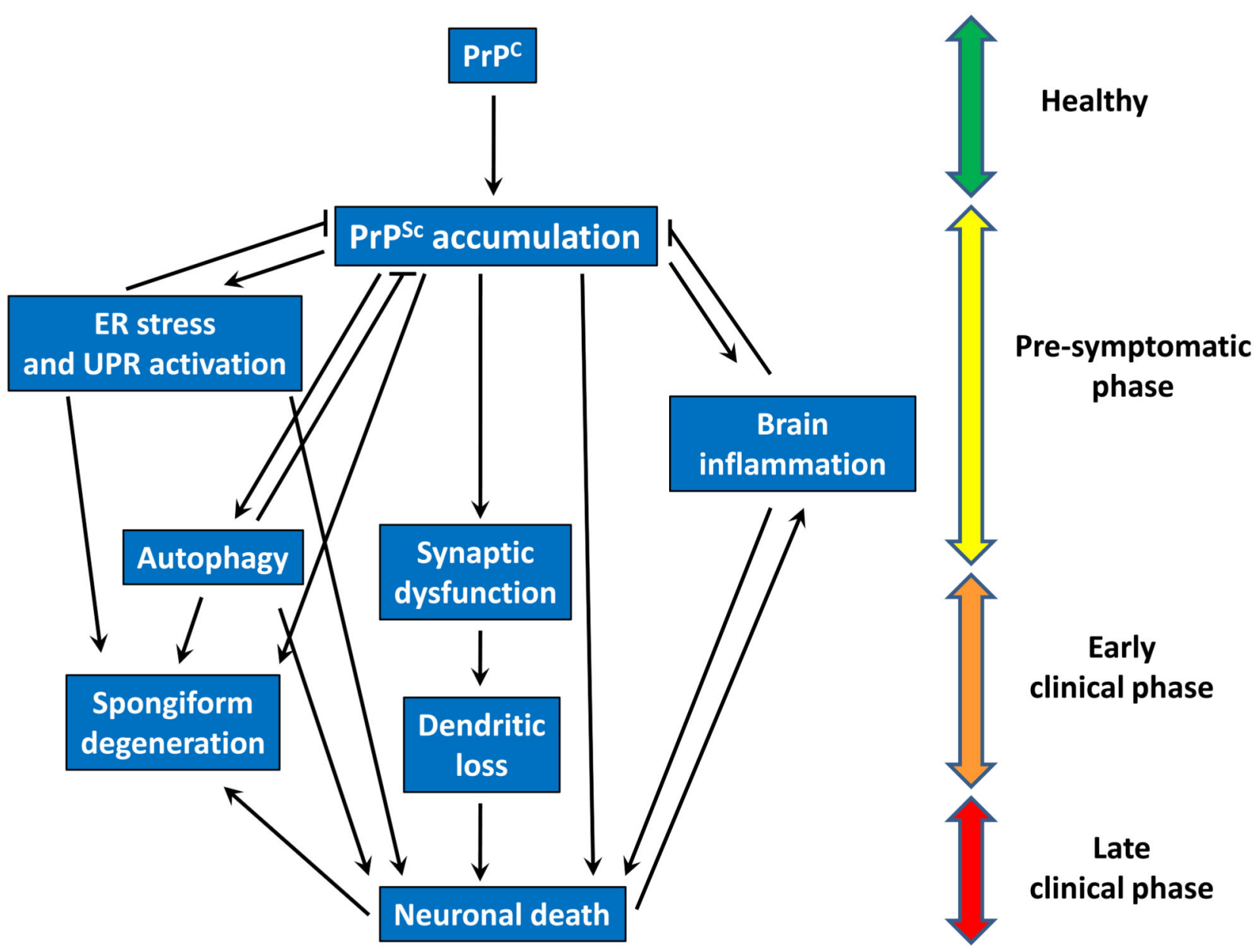

Figure 3. Schematic model of neurodegeneration in prion diseases

The disease process starts with the formation of $\mathrm{PrPSc}^{\mathrm{Sc}}$, beginning a long and clinically silent presymptomatic phase, in which $\mathrm{PrP}^{\mathrm{Sc}}$ slowly but gradually accumulates in the brain. $\operatorname{PrP} \mathrm{P}^{\mathrm{Sc}}$ accumulation triggers ER stress and activation of the UPR, which represents the first line of defense against protein misfolding. Other early consequences of $\mathrm{PrP}^{\mathrm{Sc}}$ accumulation are brain inflammation (in the form of astrocytosis and microglial activation) and autophagy. Both inflammation and autophagy might initially be defensive mechanisms, but later could also contribute to neuronal death and perhaps brain vacuolation. The first damage leading to noticeable clinical consequences is likely synaptic disruption, ending the presymtomatic phase and beginning the early clinical phase of the disease. Synaptic dysfunction produces loss of dendrites and finally neuronal death. The end and irreversible stages of the disease are characterized by massive spongiform degeneration and neuronal death, which likely are triggered by a variety of interconnecting cellular pathways. 